\section{The Cerne Giant}

The 'Cerne Giant', it is announced, will come under the auctioneer's hammer on June 16 next when the Abbey estate, Cerne Abbas, near Dorchester, Dorset, is to be sold in lots. The 'Cerne Giant' is one of a small group of remarkable and curious antiquities of Britain which were described by Sir Flinders Petrie some years ago in a special publication of the Royal Anthropological Institute. They are figures of considerable size cut in the turf on the chalk in outline. They are of unknown purpose and unknown age, though almost certainly some, if not all, are prehistoric. The best known, owing in part to its appearance in popular fiction, is the Berkshire 'White horse', but the 'Wilmington giant' in Sussex and the 'Cerne Abbas giant' are almost equally famous. The 'Wilmington giant' is on a slope so steep as almost to appear to be standing upright. The 'Cerne giant' is on Trendle or Giant's Hill, and is a huge ithyphallie figure, one hundred and eighty feet high, brandishing a. club, which is one hundred and twenty feet long and in breadth runs from seven to twenty-four feet. The head apcears disproportionately small. The outline is cut in trenches two feet broad by one foot deep. The 'Wilmington giant' is rather larger, being approximately two hundred and forty feet high, with a head of twenty-one feet breadth. Various explanations of the giants' figures have been put forward. It has been suggested that the 'Cerne giant' is the figure of the Saxon god Heil, but in all probability it is much older, possibly Iron Age. The circle above the figure of the giant in which the Cerne maypole used to stand, together with the ithyphallic character of the figure, support the obvious attribution to a very ancient fertility cult. The remarkable character of the figure and its great interest for the light it throws on ancient British culture make it regrettable that the ground on which this figure is cut should be in private ownership and subject to such vicissitudes as that now impending.

\section{Archæological Investigations in Cilicia}

A DISCOVERY of much interest in relation to the sources of supply of material for implements in the prehistoric period of the eastern Mediterranean and western Asia was the subject of reference by Prof. John Garstang in an account of recent excavation on Hittite sites in Cilicia delivered before the Society of Antiquaries of London on May 6. Archæologists have sought for some time sources of the supply of obsidian, the rare volcanic glass from which the finer types of stone implements were fashioned in Egypt, the Aegean, Greece and western Asia, and of which for long the only source known to have been available for these areas was the island of Melos. An outcrop of this material several miles across, Prof. Garstang states, has now been discovered at the foot of Mount Argaeus in Anatolia. It shows many traces of having been worked in antiquity, and implements of this material, with others of chert, have been found in the lower levels of one of two interesting sites near Mersin. The site in question, on a small river Souk Sü (Cold Water), showed signs of a pre-Hittite occupation of possibly so much as two thousand years. In describing the results obtained by the Neilson expedition to Cilicia, Prof. Garstang said that twenty-three sites on the plain of Adana had been examined, some of which yielded superficial evidence of Hittite occupation. Four sites had been opened in co-operation with the Government Museum at Adana. These included the mound at Serkeli on the east bank of the ancient Pyramus, where the important imperial Hittite monument was studied. On the mound of Kazanli, between Tarsus and Mersin, evidence was found of Hittite occupation extending from between 2400 B.c. and 2200 B.c. down to the Assyrian invasions. Prof. Garstang believes that the fall of the Hittite capital on the plateau did not involve the destruction of the Hittite centres of Cilicia.

\section{Electricity in the Hospital}

THe Faraday Lecture of the Institution of Electrical Engineers was given on May 6 by Mr. R. S. Whipple, on the subject of "Electricity in the Hospital". Dealing separately with lighting, power, heating, medical treatment and intercommunication, Mr. Whipple could easily convince his audience of the enormous call made on the electrical engineering services of a big hospital. He gave an estimate of the $\mathrm{X}$-ray photographs taken annually by the largest ten hospitals in London as a million. Electra-medicine has indeed gone a long way from the methods of the seventeenth century, when a cure for paralysis was sought by giving the patients shocks from Leyden jars. Mr. Whipple passed in review the instruments devised especially for medical use, with special reference to the electro-eardiograph and the various diathermy machines; these were also shown in action.

\section{New Zealand Handbook}

ON the occasion of the meeting of the Australasian and New Zealand Association for the Advancement of Science at Auckland on January 12-19 this year, a useful handbook to New Zealand was issued to members. The book contains some thirty short articles on various aspects of the country, but the greater part is concerned with the geology, natural history and native population. Among the most valuable chapters are those on the climate by $\mathrm{Mr}$. E. Kidson, the geomorphology of Wellington by Prof. C. A. Cotton, the economic geology of New Zealand by Mr. J. Henderson, the ecology by Mr. H. H. Allan and the forests by Mr. E. P. Turner. The volume gives in a collected form a great deal of precise information which is not otherwise easily accessible. The chapter on New Zealand's economic history discusses the future development of the resources of the Dominion.

\section{Christ's Hospital and Prof. Armstrong}

THE annual report of the Headmaster of Christ's Hospital contains the following reference to Prof. H. E. Armstrong, who, as many of our readers know, 
has been confined to his room for several months, though he maintains his interest in scientific and educational activities: "Illness has deprived the Committee of Education of the attendance of Prof. Armstrong, who, as a member of the committee for nearly forty years and latterly as chairman, may claim a large share in the formation and guidance of the Hospital's educational policy and ideals. It is a consolation to know that in his position as educational adviser to the council we shall still have the benefit of his wide knowledge and wise direction. We consider ourselves very fortunate to have as the new chairman of the Committee, the Rev. Prebendary A. Chilton, who brings to this work the special knowledge both of an old Blue and of a distinguished headmaster."

\section{Announcements}

AT a recent meeting of the Lawes Agricultural Trust Committee, Lord Clinton tendered his resignation as chairman owing to ill-health, and Prof. H. E. Armstrong was appointed in his place. Sir Merrik Burrell, lately president of the Royal Agricultural Society of England and chairman of its Research Committee, was appointed vice-chairman.

WE regret that the name of Sir Cuthbert Wallace, president of the Royal College of Surgeons, who has been made a baronet, was omitted from the list of Coronation honours published in NATURE of May 15.

THE eighth annual Haldane Memorial Lecture at Birkbeck College, London, will be delivered by Sir Arthur Eddington, director of the Observatory and Plumian professor of astronomy in the University of Cambridge, on May 26 at 6 p.m. The subject of the lecture will be "The Reign of Relativity 1915-1937". Admission is free, without ticket.

The silver jubilee of the Chadwick Lectures occurs this year and the Chadwick Trustees are holding a reception for their former and recent lecturers, scholarship holders and recipients of Chadwick Medals and Prizes, to precede the lecture on May 26 by Prof. J. G. Fitzgerald, to be given at Manson House, 26 Portland Place, at 5.30 p.m. Dr. Fitzgerald is director of the School cf Hygiene and the Connaught Laboratories, and professor of hygiene and preventive medicine in the University of Toronto. He is now on a year's leave of absence for the study of the teaching of preventive medicine in medical schools in the United States, Canada, the British Isles and other countries of Europe, for the Rockefeller Foundation. The title for Dr. Fitzgerald's lecture is "Preventive Medicine-an Avenue of Good Will". This will be the initial lecture of a series on public health ques. tions by representatives of Overseas Dominions.

THE following appointments and promotions have recently been made in the Colonial Service : J. Glover, second plant physiologist, East African Research Station, Amani, Tanganyika; K. Wilkinson, Euro- pean assistant, Meteorological Service, East Africa; N. S. Haig (agricultural officer), senior agricultural officer, Uganda ; M. C. Abraham (assistant irrigation engineer), irrigation engineer, Ceylon; F. H. Clarke (assistant game warden), senior assistant game warden, Kenya; W. G. G. Cooper (geologist), assistant director of Geological Survey, Gold Coast ; S. G. Taylor (irrigation engineer), divisional irrigation engineer, Ceylon; A. P. Weir (irrigation engineer), divisional irrigation engineer, Ceylon.

Ar the forthcoming meeting of the National Peace Congress, which will be held at Friends' House, Euston Road, London, on May 28-31, a meeting of the Science Commission is to take place with Prof. S. Chapman in the chair. Prof. P. M. S. Blackett will open the discussion on "The Responsibility of the Scientist in Relation to Peace Problems". Further information concerning the National Peace Congress may be obtained from the Secretary, 39 Victoria Street, London, S.W.1.

AN informal conference on "The Conduction of Electricity in Solids" will be held at the H. H. Wills Physical Laboratory, University of Bristol, under the joint auspices of the Physical Society and the University of Bristol, on July 13-16. Several morning and afternoon discussions have been arranged. Among those who will take part in the discussions are: Prof. R. W. Pohl (Göttingen), Dr. J. H. de Boer (Eindhoven), Prof. Borelius (Stockholm), Prof. W. L. Bragg, Dr. C. H. Desch, Prof. G. I. Finch, Dr. E. T. S. Appleyard and Prof. J. E. LennardJones. The conference will be open to members of the staffs of universities and research institutions. Further information can be obtained from Prof. A. M. Tyndall or Prof. N. F. Mott, H. H. Wills Physical Laboratory, The University, Royal Fort, Bristol, 8.

A CAtalogue of rare and valuable books (No. 609) from Francis Edwards, 83 Marylebone High Street, W.1, contains some unusually interesting volumes of voyages, including Champlain's "Les Voyages de la Nouvelle France Occidentale" (1632), Hearne's "Journey from Hudson's Bay to the Northern Ocean" (1795), Linschoten's "Discours of Voyages into ye Easte and Weste Indies" (1598), Martyr's "History of Travayle" (1577) and a unique item in the form of a twelve-page print of a letter from Sir Joseph Banks describing his voyage with Captain Cook in 1768-71.

The Oxford University Press announces that "The Science of Petroleum", edited by Dr. A. E. Dunstan, Prof. A. W. Nash, Sir Henry Tizard and Dr. A. B. T. Brooks, is approaching completion. The publishers expect to issue it in three volumes, each containing about one million words, during this summer. It contains about four hundred articles, written by three hundred contributors drawn from all parts of of the world. 